\title{
Cardinal temperatures for planting-emergence phase in gladiolus
}

\author{
Martina Muttoni ${ }^{1}$ Cleber Maus Alberto ${ }^{*}$ Alex Cristiano Bartz ${ }^{1}$ Lilian Osmari Uhlman ${ }^{2}$ \\ Vanderley de Lima Tartaglia ${ }^{1}$ Nereu Augusto Streck ${ }^{2}$
}

${ }^{1}$ Universidade Federal do Pampa (UNIPAMPA), 97650-000, Itaqui, RS, Brasil. E-mail: cleberalb@gmail.com. *Corresponding author. ${ }^{2}$ Programa de Pós-graduação em Engenharia Agrícola, Centro de Ciências Rurais (CCR), Universidade Federal de Santa Maria (UFSM), Santa Maria, RS, Brasil.

\begin{abstract}
The objective of this study was to determine the cardinal temperatures for the planting-emergence phase of gladiolus. A controlled environment experiment was performed in a growth chamber in the Universidade Federal do Pampa - Campus Itaqui, using the completely randomized experimental design with 12 temperature treatments $\left(5^{\circ} \mathrm{C}, 7^{\circ} \mathrm{C}, 10^{\circ} \mathrm{C}, 13^{\circ} \mathrm{C}, 16^{\circ} \mathrm{C}, 18^{\circ} \mathrm{C}, 20^{\circ} \mathrm{C}, 22^{\circ} \mathrm{C}, 25^{\circ} \mathrm{C}, 30^{\circ} \mathrm{C}, 33^{\circ} \mathrm{C}, 35^{\circ} \mathrm{C}\right)$ and ten replicates. Corms of the cultivar 'Amsterdam' were planted at a depth of $10 \mathrm{~cm}$ in $1.7 \mathrm{dm}^{3}$ pots. Every day the date of emergence of the gladiolus plants was observed. Then for each treatment, the emergence rate was calculated as the inverse of the duration of the budding phase, and estimated data were achieved employing the non-linear model of simulation. The lower base and upper base temperatures were identified at the non-emergence temperatures. To estimate the optimum temperature, the root of mean square error was used. Between 22 and $25^{\circ} \mathrm{C}$ the planting-emergence phase was reported to be completed in a shorter time span, although the smaller root mean square error was achieved at $22.5^{\circ} \mathrm{C}$. The cardinal temperatures of the planting-emergence phase of gladiolus, lower base, optimum and upper base temperature were $5^{\circ} \mathrm{C}$, $22.5^{\circ} \mathrm{C}$ and $35^{\circ} \mathrm{C}$, respectively.

Key words: Gladiolus x grandiflorus Hort., lower base temperature, upper base temperature, optimum temperature, development.
\end{abstract}

Temperaturas cardinais para a fase plantio-emergência de gladíolo

RESUMO: Objetivou-se determinar as temperaturas cardinais para a fase de plantio-emergência de cormos de gladiolo. O experimento foi conduzido em ambiente controlado, em câmara de crescimento localizada no laboratório de fitotecnia do Campus Itaqui da Universidade Federal do Pampa. O delineamento experimental foi inteiramente casualizado sendo os tratamentos 12 níveis térmicos $\left(5^{\circ} \mathrm{C}, 7^{\circ} \mathrm{C}, 10^{\circ} \mathrm{C}, 13^{\circ} \mathrm{C}\right.$, $16^{\circ} \mathrm{C}, 18^{\circ} \mathrm{C}, 20^{\circ} \mathrm{C}, 22^{\circ} \mathrm{C}, 25^{\circ} \mathrm{C}, 30^{\circ} \mathrm{C}, 33^{\circ} \mathrm{C}, 35^{\circ} \mathrm{C}$ ), com dez repetiçoes. Utilizou-se a cultivar 'Amsterdam', sendo o plantio dos cormos a $10 \mathrm{~cm}$ de profundidade. Foi observada diariamente a data de emergência das plantas de gladiolo. A taxa de emergência foi calculada para cada tratamento como o inverso da duração da fase de brotação, sendo os dados estimados obtidos através de um modelo não linear de simulação. Nas temperaturas que não houve emergência, definiu-se a temperatura basal inferior e basal superior. Para determinar a temperatura ótima, utilizou-se a raiz do quadrado médio do erro. Na faixa de temperatura de $22^{\circ} \mathrm{C}$ a $25^{\circ} \mathrm{C}$ a fase plantio-emergência é completada em menor tempo, porém a menor raiz quadrada do erro foi obtida na temperatura de $22,5^{\circ} \mathrm{C}$. As temperaturas cardinais para a fase plantio-emergência de gladiolo são temperatura basal inferior de $5^{\circ} \mathrm{C}$, temperatura ótima de $22,5^{\circ} \mathrm{C}$ e temperatura basal superior de $35^{\circ} \mathrm{C}$.

Palavras-chave: Gladiolus x grandiflorus Hort., Temperatura basal inferior, temperatura basal superior, temperatura ótima, desenvolvimento.

\section{INTRODUCTION}

Gladiolus (Gladiolus x grandiflorus Hort.), Iridaceae family, is an important cut flower propagated from corms. Naturally occurring in the Mediterranean and southern Africa, the wild gladiolus includes more than 100 species (TOMBOLATO et al., 2004). In Brazil, the gladiolus has the greatest market during the All Souls Day holiday. The commercial portion of the plant is its inflorescence, a spike bearing several multi-hued florets. This herbaceous, bulbous plant has elongated and lanceolate leaves with waxy cuticles and parallel veins. With a relatively short duration cycle (65 to 120 days), low planting costs, quick financial returns and easy transportation, this cut follower crop is very attractive to growers (PAIVA et al., 1999).

Air temperature is the main meteorological variable that affects the gladiolus developmental 
cycle (STRECK et al., 2012), with three cardinal temperatures, the lower base (Tb), optimum (Tot) and upper base (TB) temperatures (YAN \& HUNT, 1999). The $\mathrm{Tb}$ and $\mathrm{TB}$ temperatures represent, respectively, the temperatures below and above which plant development is absent or negligible, and Tot is the temperature at which the plant development rate is at the maximum (BONHOMME, 2000).

Although the gladiolus plants are frost intolerant, they adapt well to daytime temperatures of $10-25^{\circ} \mathrm{C}$ and nighttime temperatures of $16-18^{\circ} \mathrm{C}$; they can also endure temperatures up to $50^{\circ} \mathrm{C}$ provided they have optimal ranges of air and soil moisture (SHILLO \& HALEVY, 1976). STRECK et al. (2012) reported a lengthening of the crop cycle at lower temperatures and reduction when the temperatures rise.

SCHWAB et al. (2015) formulated the phenological scale for gladiolus in which four phases are evident in the developmental cycle: dormancy phase, sprouting phase (from filiform roots appearance to sheaths appearance), vegetative phase (from emergence of the first leaf tip to emergence of the final leaf tip on the stem) and reproductive phase (from heading to plant senescence).

Thereafter, a developmental simulation model called PhenoGlad was built for gladiolus based on this phenological scale (UHLMANN et al., 2017). In this model, the dates of the occurrence of the developmental stages of the gladiolus are described with air temperature being the main input variable. At each developmental stage, the specific cardinal temperatures must be identified to enable the calculation of the daily development rate and thus simulate the crop cycle. Hence, identifying the cardinal temperatures becomes crucial to successfully employ this mathematical model.

Emergence is one of the most significant events that directly influence the success of annual crops; its appearance must be fast, uniform and total so that a good productive potential is reached (SOLTANI et al., 2006). During unfavorable conditions, the propagating material may be susceptible to soil pathogen attacks because of the increased exposure time, causing corm failure to sprout. Temperature variations can exert adverse effects on the speed, percentage, and uniformity of emergence. Therefore, it is important to identify the temperatures at which the efficiency of the emergence process is at its maximum, as well as the minimum and maximum extremes during which no emergence occurs.

Another practical application of knowing the cardinal temperatures is in the calculation of thermal time, in degree-day units. Thermal time implies the accumulation of favorable daily temperatures, which is a better biological time descriptor than days of the calendar time (GILMORE \& ROGERS, 1958). To calculate the thermal time, several methods (ROSA et al., 2009) are available, wherein the cardinal temperatures of each developmental phase of the crop must be known. Besides, gladiolus corms experience the dormancy phase, and only on exposure to specific temperature conditions do they begin the budding phase. Estimation of the $\mathrm{Tb}$ is also crucial to enable the storage of the gladiolus corms under suitable temperature conditions.

The cardinal temperatures are normally determined under field conditions, at different sowing/planting times, to ensure that the plants are subjected to different thermal conditions (SOUZA $\&$ MARTINS, 2014). However, the lower base and upper base temperatures rarely occur under field conditions in southern Brazil, which predominantly experiences subtropical climate, necessitating further study in temperature-controlled environments.

From the literature 5,25 and $35^{\circ} \mathrm{C}$ are the values assumed for the lower base, optimum and upper base temperatures, respectively (UHLMANN et al., 2017). Obtained from field experiments, these cardinal temperatures are noted without the influence of the other factors that may affect the accuracy of determination. Thus, determining the cardinal temperatures in a controlled environment can minimize the experimental errors and improve their estimation and, thereby, resulting in a greater accuracy of estimating the duration of the planting-emergence phase. The objective of this study was to determine the cardinal temperatures for the planting-emergence phase of gladiolus using a controlled environment experiment.

\section{MATERIALS AND METHODS}

Controlled environment experiments were performed in a phytotron growth chamber $\left(\mathrm{Climamont}^{\circledR}\right.$ ), with temperatures between 5 and $25^{\circ} \mathrm{C}$ and in a climatic chamber (Quimis ${ }^{\circledR}$ ) for temperatures higher than $25^{\circ} \mathrm{C}$, both having temperature and humidity control at the Plant Breeding Laboratory of the Universidade Federal do Pampa - Campus Itaqui (latitude 29 $09^{\prime} 21.68^{\prime \prime} \mathrm{S}$ and longitude 56 $33^{\prime} 02.58^{\prime \prime}$ $\mathrm{W}$, at $74 \mathrm{~m}$ altitude). Air temperature inside the chambers were monitored with a digital thermometer. The experimental design was completely randomized, with 12 temperature treatments: $5^{\circ} \mathrm{C}, 7^{\circ} \mathrm{C}, 10^{\circ} \mathrm{C}$, $13^{\circ} \mathrm{C}, 16^{\circ} \mathrm{C}, 18^{\circ} \mathrm{C}, 20^{\circ} \mathrm{C}, 22^{\circ} \mathrm{C}, 25^{\circ} \mathrm{C}, 30^{\circ} \mathrm{C}, 33^{\circ} \mathrm{C}$, $35^{\circ} \mathrm{C}$, and ten replications. A $1.7 \mathrm{dm}^{3}$ pot was used as the experimental unit. 
Vernalized corms of the Amsterdam cultivar with 14 and $16 \mathrm{~cm}$ circumference were used. This cultivar is widely commercially used in Brazil. The corms had been stored at an average temperature of $5^{\circ} \mathrm{C}$ before planting. Planting was done at $10 \mathrm{~cm}$ depth in the pots filled with upper layer of a Plinthudult soil. Soil-filled pots were then placed in the chambers, 24 hours prior to the time the corms were planted. The soil moisture was maintained close to field capacity with irrigation, and all the pots were given the same amount of water. In all treatments, the relative humidity was kept at $80 \%$.

Once planting was done, each pot was observed every day until day of emergence of the gladiolus plants, which was considered when buds were visible above the soil surface. Emergence date was considered when half the number of plants emerged above ground level.

For each treatment, the emergence rate $\left(\right.$ day $\left.^{-1}\right)$ was calculated as the inverse of the duration of the sprouting phase (from planting to emergence), i.e. 1 divided by the number of days when $50 \%$ emergence was visible. For each treatment, emergence rate was normalized by dividing the emergency rates by the highest emergence rate that occurred at the optimal temperature. The data ranging from 0 to 1 , and it constituted the response curve of emergence rate as function of temperature $[\mathrm{f}(\mathrm{T})]$.

To the observed data, a version of the beta function used by WANG \& ENGEL (1998), called WE model, with $\mathrm{f}(\mathrm{T})$ ranging from 0 to 1 , was fitted. This function has the following characteristics: (1) if temperature is equal to or below the lower base temperature $(\mathrm{Tb})$, or equal to or higher than the upper base temperature (TB), the function is zero, implying that no development occurs under these conditions; (2) the beta function equals to one when the temperature is equal to the optimum temperature (Topt), and has a value below one but higher than zero in the intermediate conditions. The beta version of the WE function $[f(\mathrm{~T})]$ is:

$f(\mathrm{~T})=0, \mathrm{~T} \leq \mathrm{Tb}$ or $\mathrm{T} \geq \mathrm{TB}$

$f(\mathrm{~T})=\left[2 .(\mathrm{T}-\mathrm{Tb})^{\alpha} \cdot(\mathrm{Topt}-\mathrm{Tb})^{\alpha}-(\mathrm{T}-\mathrm{Tb})^{2 \cdot \alpha}\right] /(\mathrm{Topt}-$

$\mathrm{Tb})^{2 . \alpha}, \mathrm{Tb} \leq \mathrm{T} \leq \mathrm{TB}$

$\mathrm{a}=\ln (2) / \ln [(\mathrm{TB}-\mathrm{Tb}) /($ Topt-Tb)]

where Tb, Topt, and TB are the lowerbase, optimum and upper base cardinal temperature for planting-emergence phase, respectively, and $\mathrm{T}$ is the average daily air temperature.

The temperatures at which no emergence of plants was observed in the experiments were assumed as the lower and upper base temperatures. Optimum temperature was determined by testing several Topt values in the WANG \& ENGEL (1998) equation. For each optimum temperature tested $\left(22^{\circ} \mathrm{C}, 22.5^{\circ} \mathrm{C}\right.$, $23^{\circ} \mathrm{C}, 23.5^{\circ} \mathrm{C}, 24^{\circ} \mathrm{C}, 24.5^{\circ} \mathrm{C}$ and $25^{\circ} \mathrm{C}$ ), the root mean square error (RMSE) was determined according to BORGES et al. (2010):

$\operatorname{RMSE}=\left(\Sigma\left(\mathrm{s}_{\mathrm{i}}-\mathrm{o}_{\mathrm{i}}\right)^{2} / \mathrm{N}\right)^{0,5}$

where " $\mathrm{s}$ " is the estimated value, "o" is the observed value and $\mathrm{N}$ the number of observations. Thus, "RMSE" indicates the mean error of Topt; therefore, the lower the RMSE, the better the model fit and the greater the accuracy of the Topt simulation by the temperature function proposed by WANG \& ENGEL (1998).

\section{RESULTS AND DISCUSSION}

No emergence of the gladiolus plants was observed at 5 and $35^{\circ} \mathrm{C}$ (Table 1). For 76 days the corms that were kept below $5^{\circ} \mathrm{C}$ showed no

Table 1 - Duration of the planting-emergence phase (PL-EM) in gladiolus (Gladiolus x grandiflorus Hort.), cultivar 'Amsterdam', under different temperatures, with their respective normalized emergence rates.

\begin{tabular}{lcc}
\hline Temperature $\left({ }^{\circ} \mathrm{C}\right)$ & PL-EM (days) & Normalized emergency rate \\
\hline 5 & 76 & 0 \\
\hline 7 & 64 & 0.2031 \\
10 & 30 & 0.4329 \\
13 & 20 & 0.6500 \\
16 & 18 & 0.7228 \\
18 & 15 & 0.8667 \\
20 & 14 & 0.9286 \\
22 & 13 & 1.0000 \\
25 & 13 & 1.0000 \\
30 & 15 & 0.8667 \\
\hline 35 & 19 & 0.6842 \\
\hline
\end{tabular}


morphological alteration. At $35^{\circ} \mathrm{C}, 30$ days after planting the corms progressively degenerated without producing radicles or sprouting. SHILLO \& SIMCHON (1973) also noted the lack of budding below $5^{\circ} \mathrm{C}$. In the case of seeds, the slow drop in temperature affects the rates of imbibition and mobilization of reserves, which in turn results in a slowing down of the germination process (MARCOS FILHO, 2015).

In the case of reproductive propagation plant parts like sugarcane sticks, sprouting which is a biological process draws energy from the breakdown of reserves via the respiratory cycle (MAGRO et al., 2011). At temperatures below $5^{\circ} \mathrm{C}$, potato (Solanum tuberosum), showed a decline in the respiratory rates, with lower rate of tuber sprouting (TAIZ \& ZAIGER, 2009). BONHOMME (2000) reported that at very low temperatures specific enzymes are insufficiently flexible and; therefore, unable to effectively perform in a reaction.

UHLMANN et al. (2017) tested five thermal levels in the plantlet emergence phase of gladiolus and also reported absence of emergence at $35^{\circ} \mathrm{C}$. TAIZ \& ZEIGER (2009) also reported that respiration increases considerably between 0 and $30^{\circ} \mathrm{C}$, and achieves the maximum between 40 and $50^{\circ} \mathrm{C}$. At higher temperatures, the respiration rate drops again, because the enzymes responsible for respiration are inactivated. When exposed to temperatures higher than the optimum, the emergence rate of the gladiolus corms declines until the temperature reaches $35^{\circ} \mathrm{C}$ and for temperatures above this the emergence does not happen.

Elevated temperatures also decrease the cell membrane stability, causing alterations in the composition and structure, resulting in ion loss. The membrane rupture also inhibits respiration and photosynthesis as both processes rely on the enzymes and electron carriers bound to the membranes (TAIZ \& ZEIGER, 2009). Therefore, the budding process of gladiolus, that is dependent on respiration, is impaired.

Between 22 and $25^{\circ} \mathrm{C}$ the duration of planting-emergence phase occurred much faster, within 13 days (Table 1 ). The lowest RMSE value occurred at $22.5^{\circ} \mathrm{C}$ in the WE model (Figure 1B), revealing this temperature as the optimum for the planting-emergence phase of gladiolus.

Results of this study differed from those reported by UHLMANN et al. (2017) who suggested $25^{\circ} \mathrm{C}$ as the optimum temperature for the phase in gladiolus under consideration. This difference is attributed to the different methodologies employed between the studies. In their study UHLMANN et al. (2017) tested only five thermal levels $\left(5^{\circ} \mathrm{C}\right.$, $16^{\circ} \mathrm{C}, 25^{\circ} \mathrm{C}, 30^{\circ} \mathrm{C}, 35^{\circ} \mathrm{C}$ ) which produced only one optimum temperature $\left(25^{\circ} \mathrm{C}\right)$. In the case of potato (Solanum tuberosum), which also possesses an organ of vegetative propagation, the emergence phase was observed at the optimal temperature range of 22 to $25^{\circ} \mathrm{C}$ (MIDMORE, 1984), a finding that agrees with the results for the gladiolus corms in this study.

Figure 2 shows that when using the Topt of $22.5^{\circ} \mathrm{C}$ the WANG \& ENGEL (1998) model showed better simulation of the temperature function when compared to using the Topt of $25^{\circ} \mathrm{C}$ in PhenoGlad. Thus, the best prediction of the estimated data occurred when $22.5^{\circ} \mathrm{C}$ optimum temperature is used.

It is crucial to identify the optimum temperature of the planting-emergence phase because emergence is regarded as the most significant isolated event that affects the annual crop production (SOLTANI, 2006). To enable quick and uniform emergence, budding must occur under near ideal environment conditions. CALLEJAS et al. (2014) reported that the respiration, photosynthesis, growth and developmental rates are dependent on temperature. Therefore, it is vitally important to know the optimum temperature at which these processes are not adversely affected.

The values of the cardinal temperatures for the planting-emergence phase in gladiolus obtained in the current study will be a good basis for improving the PhenoGlad model. Besides, by knowing the lower base temperature, corms can be stored by the producer at $5^{\circ} \mathrm{C}$ to prevent budding. Knowledge regarding the optimum temperature will enable the farmers to plant at the most suitable time, namely, when the planting-emergence phase takes the shortest time to complete.

\section{CONCLUSION}

The cardinal temperatures for the gladiolus planting-emergence phase are $5^{\circ} \mathrm{C}$, $22.5^{\circ} \mathrm{C}$ and $35^{\circ} \mathrm{C}$ for base, optimum and maximum temperature, respectively. 

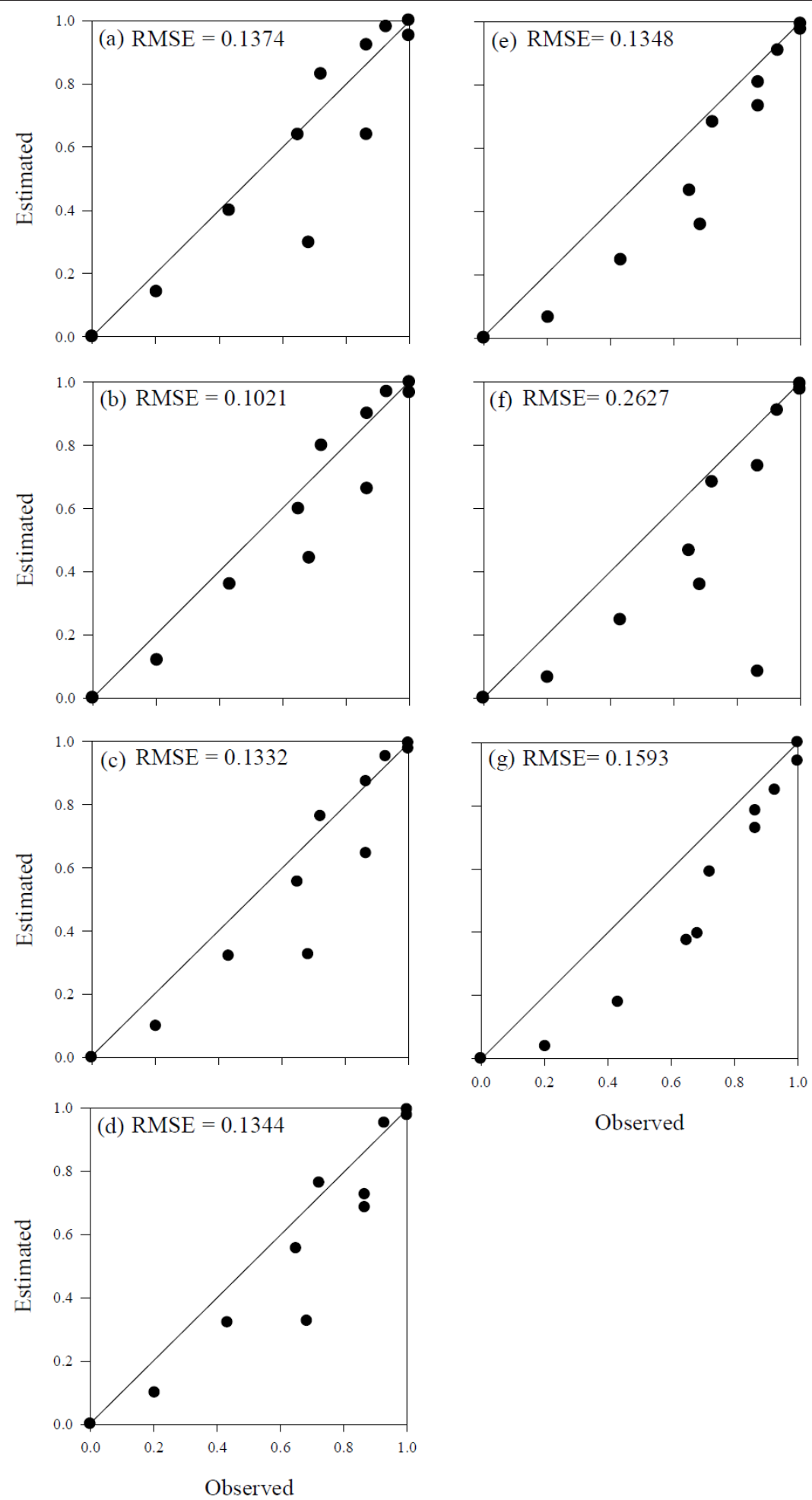

Observed

Figure 1 - The root mean square error (RMSE) of the observed emergence values and estimated by the equation of WANG \& ENGEL (1998) using several optimum temperatures: $\mathrm{a}=22.0^{\circ} \mathrm{C}, \mathrm{b}=22.5^{\circ} \mathrm{C}, \mathrm{c}=23.0^{\circ} \mathrm{C}, \mathrm{D}=23.5^{\circ} \mathrm{C}, \mathrm{e}=24.0^{\circ} \mathrm{C}, \mathrm{f}=$ $24.5^{\circ} \mathrm{C}, \mathrm{g}=25.0^{\circ} \mathrm{C}$. 


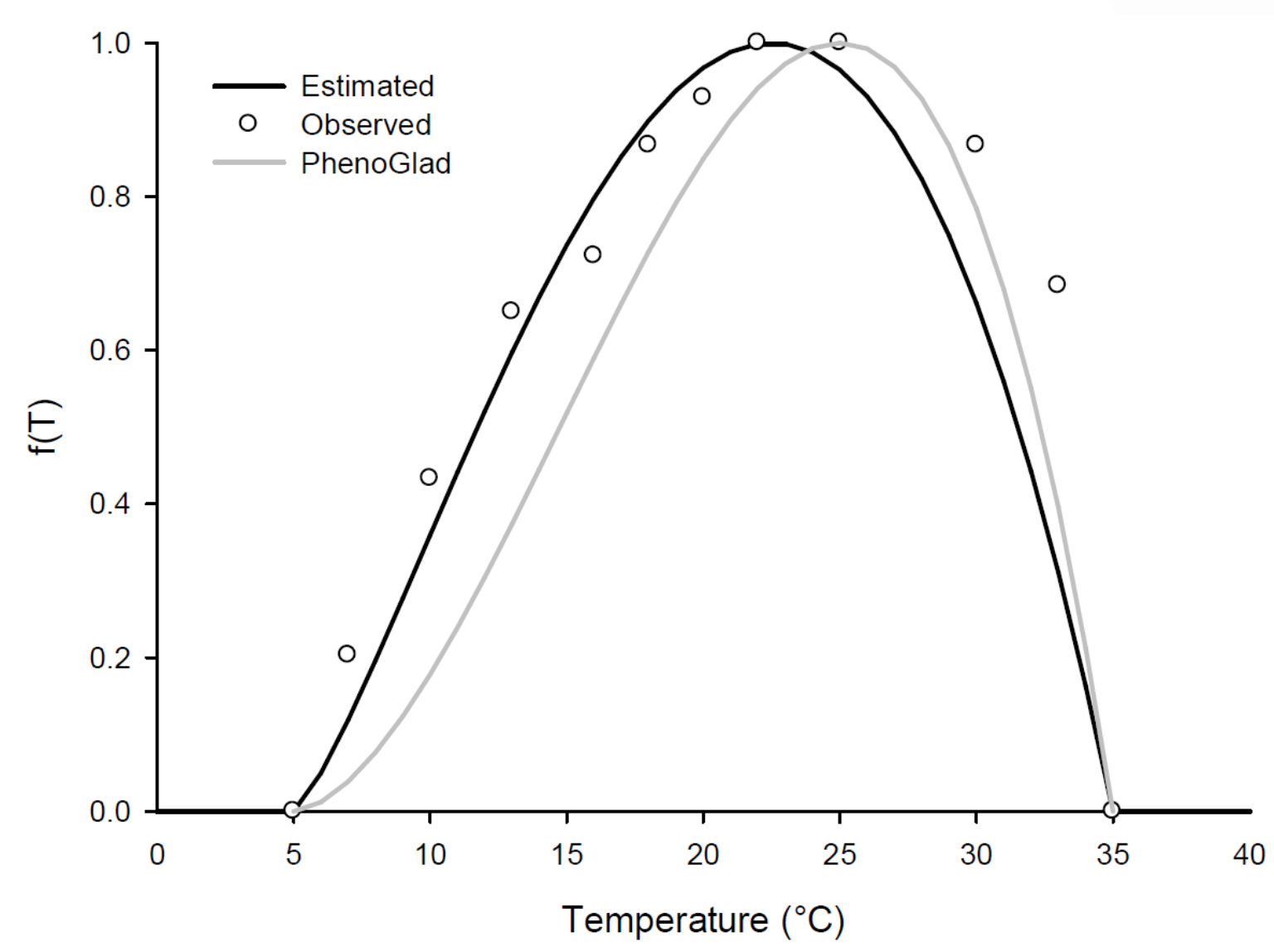

Figure 2 - The temperature response [ $\mathrm{f}(\mathrm{T})]$ for the planting-emergence phase of the gladiolus cultivar 'Amsterdam'. Curve estimated with the equation of WANG \& ENGEL (1998) using $\mathrm{Tb}=5^{\circ} \mathrm{C}$, Tot $=22.5^{\circ} \mathrm{C}$ and $\mathrm{TB}=35^{\circ} \mathrm{C}$ (estimated); data recorded in the experiment at different temperatures (circles); curved estimated by the Wang \& Engel (1998) equation used in the PhenoGlad model using $\mathrm{Tb}=5^{\circ} \mathrm{C}$, Tot $=25^{\circ} \mathrm{C}$ and $\mathrm{TB}=35^{\circ} \mathrm{C}$. The beta function version used in the WE model is: $f(\mathrm{~T})=0, \mathrm{~T} \leq \mathrm{Tb}$ or $\mathrm{T} \geq \mathrm{TB} ; f(\mathrm{~T})=\left[2 .(\mathrm{T}-\mathrm{Tb})^{\alpha}\right.$. $\left.(\mathrm{Topt}-\mathrm{Tb})^{\alpha}-(\mathrm{T}-\mathrm{Tb})^{2 . \alpha}\right] /(\mathrm{Topt}-\mathrm{Tb})^{2 . \alpha}, \mathrm{Tb} \leq \mathrm{T} \leq \mathrm{TB} ; \mathrm{a}=\ln (2) / \ln$ $[(\mathrm{TB}-\mathrm{Tb}) /(\mathrm{Topt}-\mathrm{Tb})]$ where $\mathrm{Tb}$, Topt, and TB are the base, optimum and maximum cardinal temperature for plantingemergency phase, respectively, and $\mathrm{T}$ is the average daily air temperature.

\section{REFERENCES}

BONHOMME, R. Bases and Limits to using 'degree.day' units. European Journal of Agronomy, v.13, p.1-10, 2000. Available from: $\quad<$ https://www.researchgate.net/publication/222664145 Bases_and_limits_to_using_'degreeday'_units $>$. Accessed: Jul. 20, 2016. doi: 10.1016/S1161-0301(00)00058-7.

BORGES, V.P. et al. Evaluating models for estimation of incoming solar radiation in Cruz das Almas, Bahia, Brazil. Revista Brasileira de Engenharia Agrícola e Ambiental, v.14, p.74-80, 2010 Available from: <http://www.scielo.br/scielo.php?script=sci_artt ext\&pid=S1415-43662010000100010>. Accessed: Jul. 18, 2016. doi: $10.1590 / \mathrm{S} 1415-43662010000100010$.

CALLEJAS, I.J.A. et al. Determination of the cardinal temperatures of Purple mango cultivar through computer simulation using a nonlinear model. Ambiência, v.10, p.97-110,
2014. Available from: <http://revistas.unicentro.br/index.php/ ambiencia/article/view/1855/0>. Accessed: Jul. 20, 2016. doi: 10.5935/ambiencia.2014.01.08.

GILMORE, E.C. Jr.; ROGERS, J.S. Heat units as a method of measuring maturity in corn. Agronomy Journal, v.50, p.611-615, 1958. Available from: $<$ https://dl.sciencesocieties.org/publications/ aj/abstracts/50/10/AJ0500100611>. Accessed: Jul. 19, 2016. doi: 10.2134/agronj1958.00021962005000100014x.

MAGRO, F.J. et al. Biometria em cana de açucar. Universidade de São Paulo - Escola Superior de Agricultura "Luiz de Queroz". Piracicaba, São Paulo, 2011. Available from: <http://www.lpv. esalq.usp.br/lpv0684/Biometria $\% 20 \mathrm{em} \% 20$ cana-de-acucar $\% 20$ exemplo\%20de \%20texto\%20aluno.pdf> Accessed: May 27, 2016.

MARCOS-FILHO, J. Fisiologia de Sementes de Plantas Cultivadas. Londrina: ABRATES, 2015. 659p.

Ciência Rural, v.47, n.10, 2017. 
MIDMORE, D.J. The potato (Solanum spp.) in the hot tropics I. Soil temperature effects on emergence, plant development and yield. Field Crops Research, v.8, p.255-271, 1984. Available from: $<$ https://www.researchgate.net/publication/248422709 Potato Solanum_spp_in_the_hot_tropics_I_Soil_temperature_effects on_emergence_plant_evevelopment_and_yield $>$. Accessed: Jul. 19, 2016. doi: 10.1016/0378-4290(84)90073-X.

PAIVA, P.D.O. et al. Cultura do Gladíolo. Lavras: Departamento de Agricultura, 1999. 12p.

ROSA, H.T. et al. Thermal time methods and sowing dates in phyllochron determination in wheat cultivars. Pesquisa Agropecuária Brasileira, v.44, p.1374-1382, 2009. Available from: $<$ http://www.scielo.br/scielo.php?script=sci_arttext\&pid=S0100204X2009001100002>. Accessed: Jul. 18, 2016. doi: 10.1590/ S0100-204X2009001100002.

SCHWAB, N.T. et al. A phenological scale for the development of Gladiolus. Annals of Applied Biology, v.166, n.3, p.496-507, 2015. Available from: <http://site.ufsm.br/arquivos/uploaded/ uploads/510bb217-7730-4000-af4d-475f1543b59b.pdf $>$. Accessed: Jul. 15, 2016. doi: 10.1111/aab.12198.

SHILLO, R.; SIMCHON, S. Effect of water content and storage temperature of gladiolus corms on flowering. Scientia Horticulturae, v.1, p.57-62, 1973. Available from: $<$ http://www. sciencedirect.com/science/article/pii/030442387390006X >. Accessed: Jul. 17, 2016. doi: 10.1016/0304-4238(73)90006-X.

SHILLO, R.; HALEVY, A.H. The effects of various environmental factors on flowering of gladiolus. III. Temperature and moisture, Scientia Horticulturae, v.4, p.147-155, 1976. Available from: $<\mathrm{http} / /$ www.sciencedirect.com/science/article/pii/S0304423876800064>. Accessed: Jul. 19, 2016. doi: 10.1016/S0304-4238(76)80006-4.

SOLTANI, A. et al. Modelling seedling emergence in chickpea as influenced by temperature and sowing depth. Agricultural and Forest Meteorology, v.138,p.156-167, 2006. Available from: <http://
www.sciencedirect.com/science/article/pii/S0168192306001195>. Accessed: jul. 19, 2016. doi:10.1016/j.agrformet.2006.04.004.

SOUZA, P.M.B.; MARTINS, F.B. Estimativa da temperatura basal inferior para as cultivares de oliveira Grappolo e Maria da Fé. Revista Brasileira de Meteorologia, v.29, p.307-313, 2014. Available from: <http://www.scielo.br/scielo.php?pid=S0102$77862014000200013 \&$ script $=$ sci_abstract\&tlng=pt $>$. Accessed: Jul. 19, 2016. doi: 10.1590/S0102-77862014000200013.

STRECK, N.A. et al. Vegetative and reproductive development in gladiolus. Ciência Rural, v.42, p.1968-1974, 2012. Available from: $<$ http://www.scielo.br/scielo.php?script $=$ sci arttext\&p id $=$ S0103-84782012001100010 $>$. Accessed: Jul. 19, 2016. doi: 10.1590/S0103-84782012001100010

TAIZ, L.; ZEIGER, E. Plant physiology. Porto Alegre: Artmed, 2009. 848p.

TOMBOLATO, A.F.C. et al. Cultivo Comercial de Plantas Ornamentais. Campinas: Instituto Agronômico, 2004. 211p.

UHLMANN, L.O. PhenoGlad: Um modelo de simulação do desenvolvimento em gladíolo. 2016. 119 p. Dissertação (Mestrado) - Curso de pós graduação em agronomia, Universidade Federal de Santa Maria.

WANG, E.; ENGEL, T. Simulation of phenological development of wheat crops. Agricultural Systems, v.58, p.1-24, 1998. Available from: <http://www.sciencedirect.com/science/article/ pii/S0308521X98000286>. Accessed: Jul. 10, 2016. doi: 10.1016/ S0308-521X(98)00028-6

YAN, W.K.; HUNT,L.A. An equation for modelling the temperature response of plants using only the cardinal temperatures. Annals of Botany, v.84, p.607-614, 1999. Available from: <https://academic.oup.com/aob/article-lookup/ doi/10.1006/anbo.1999.0955>. Accessed: Jul. 10, 2016. doi: 10.1006/anbo.1999.0955 